\title{
The Cognitive Approach to Teaching \\ Students English Terminological Lexis of the Subject Field of «Microeconomics»
}

\section{Когнітивний підхід у навчанні студентів англійської термінолексики предметної галузі «мікроекономіка»}

\section{Liudmyla Naumenko ${ }^{1}$}

Dr. in Philology, Assistant Professor
Людмила Науменко ${ }^{1}$

доктор філологічних наук, доцент

E-mail: v-naumenko@ukr.net

orcid.org/0000-0002-4325-1673

Oksana Oliynyk ${ }^{2}$

Ph.D. in Philology,

Lecturer
Оксана Олійник ${ }^{2}$

кандидат філологічних наук, викладач

E-mail: roxyletters@gmail.com orcid.org/0000-0002-5701-7132

${ }^{1}$ Taras Shevchenko National

University of Kyiv

14, T. Shevchenko Blvd., Kyiv, Ukraine, 01030

${ }^{2}$ Volodymyr Vinnychenko

Central Ukrainian State

Pedagogical University

$\triangle 1$, Shevchenko Str.,

Kropyvnitskyi, Ukraine, 25006
${ }^{1}$ Київський національний університет імені Тараса Шевченка $\triangle$ бул. Т. Шевченка, 14, м. Київ, Україна, 01030

${ }^{2}$ ДВНЗ «Центральноукраїнський державний університет імені Володимира Винниченка»

$\triangle$ вул. Т. Шевченка, 1, м. Кропивницький, Україна, 25006

Original manuscript received March 29, 2018

Revised manuscript accepted October 09, 2018

\section{ABSTRACT}

The paper is devoted to study of prerequisites of applying cognitive approach to teaching English terminological lexis of the subject field of "microeconomics» 
The Cognitive Approach to Teaching Students English Terminological...

of students of non-special higher educational establishments. Such notions as "cognition», "memory», "attention», "thinking», "intelligence» that provide student's mental activity in the process of studying have been considered. The system of cognitive exercises on learning English economic terminology that contains seven types, i.e.: exercises on choice of proper lexical information, grouping, guesswork from the context, logic thinking, formulating scientific definitions, language game, associative thinking, problem-solving, and is based on logic operations of comparison, identification, division / disjuncture, integration / conjuncture, analysis and synthesis, deduction, abstraction, generalization, classification, typology, categorization, conceptualization, formulation of notions and judgements. The exercises have been chosen according to thematic principle (the topic "Marketing» from the author's manual "Business English Course») and include the following kinds: identifying a key word, identifying an odd word, multiple choice, finding out a particular name, grouping the words according to their semantic combinability, guesswork from the context, formulation of definitions, solving the crossword, filling in the radial diagram of the mental map by language reactionsassociations to the word "marketing», problem-solving of the real-like situation dealing with marketing activity in small groups and proposing a business solution. The selected exercises develop heuristic capabilities, analytic skills, logics of thinking and creative imagination of students, facilitate memorizing, strengthen attention, intensify subject and foreign languages knowledge, help to acquire new knowledge, structure information in verbal and visual forms, motivate research activity.

Key words: cognitive approach, terminological lexis, subject field of "microeconomics», logic operations of thinking, cognitive methodology.

\section{Вступ}

Акумулювання знання будь-якої предметної сфери передбачає засвоєння масиву галузевої термінолексики, що також справедливо i для такої популярної галузі, як «мікроекономіка», тим паче якщо мова йде про іiі іншомовний пласт. У сучасному глобалізованому світі англійська мова усе інтенсивніше набуває ознак мови міжкультурного спілкування, особливо у таких суспільних галузях, як політика, міжнародні відносини, інформатика, міжнаціональна (глобальна) логістика та бізнес. Ці причини викликають природний інтерес до мови економіки та бізнесу, сприяють іï вивченню не тільки в економічних вишах, а й у нефахових навчальних закладах, на природничих і гуманітарних факультетах інститутів та університетів України. 
Когнітивний підхід у навчанні студентів англійськоӥ термінолексики...

Накопичення та активізація економічного вокабуляру багато в чому залежить від усвідомленого, раціонального сприйняття спеціальних понять і лексики на їх позначення. Когнітивний підхід, що активно розвивається у вітчизняній та світовій психології, когнітології, психонометриці, психолінгвістиці та лінгводидактиці (Боднар, 2014; Борщовецька, 2004; Крупченко, 2015; Мельник, 2014; Akin, 2017; Alloway, 2013; Astor, 2008; Channel, 1996; Chein, 2010; Conway, 2003; Hassan, 2016; Huang, 2015; Jaeggi, 2011; Shipstead, 2012; Vovk, 2014), покликаний вирішити непросте завдання, яке полягає не тільки в запам'ятовуванні іншомовних слів і виразів, а й в опануванні понять, явищ, процесів, механізмів, законів та інших феноменів, які вони позначають. У світовій науковій традиції запропоновано низку моделей, які прояснюють механізми роботи людської свідомості й слугують підгрунтям для навчальних методик і практик, зокрема: модель перехресних множин Роберта Солсо, або верифікація значення слова спочатку за основними i визначальними, а потім другорядними ознаками (Solso, 2001); модель семантичного простору (метод семантичного диференціала Ч. Осгуда), що полягає в оцінюванні стимулів за тримірною шкалою: «оцінка - сила - активність», за якою визначають однорідні поняття (Semantic, 1969); просторово-функціональна модель, яка відображає процес категоризації або тематизації понять, як напр., вивчення іноземних слів за темами: «management», «marketing», «finance»; модель прототипів Елеонори Рош, яка пояснює сприйняття понять на основі природних категорій або типових прикладів (прототипів), що сприймаються людиною як «найкращі зразки» і легко запам'ятовуються (Rosh, 1983); модель семантичних універсалій (примітивів) Анни Вежбицькі (Wierzbizka, 1972), яка полягає у зведенні усього вокабуляру природної мови до невеликої кількості базових слів, які відображають певні категорії і є основою розуміння світу.

Попри популярність й уживаність поняття «когнітивний підхід» у сучасній методичній літературі, залишаються не до кінця з'ясовані такі питання, як психологічні передумови когнітивного навчання та кореляція між логічними операціями мислення i системою лінгвістичних вправ, спрямованих на опанування іншомовної галузевої термінолексики. 
The Cognitive Approach to Teaching Students English Terminological...

Мета статті полягає у вивченні передумов когнітивного підходу у навчанні студентів, встановленні кореляції між логічними операціями мислення і типами лексичних вправ, розробленні системи когнітивно орієнтованих вправ для навчання студентів нефахових вишів іншомовної галузевої термінолексики.

\section{Методи та методики дослідження}

Застосування когнітивного підходу у викладанні іншомовної галузевої термінолексики студентам вишів спирається на принцип навчання, орієнтований на студента як сформовану особистість у комплексі його психофізичних, інтелектуальних та індивідуальних характеристик, мотиваційних настанов та інтенцій i такий, що вимагає індивідуального підходу до кожного суб'єкта навчання. Серед психофізичних методів застосовуємо, у першу чергу, когнітивний підхід та інтегральний метод вивчення дисциплін через мову-посередника (Content and Language Integrated Learning / $C L I L)$. Когнітивний підхід полягає в апеляції до інтелектуальних здібностей студента, задіянні таких форм свідомості, як когніція, пам'ять, мислення, увага, інтелект, та розвиток інтелектуальнокогнітивного потенціалу суб'єкта в процесі навчально-пізнавальної діяльності. Метод вивчення дисциплін через мову-посередника, запропонований Д. Мешем у 1994 р., має на меті опанування змісту дисципліни (історія, географія, економіка та ін.) за допомогою іноземної або другої мови, передбачаючи тим самим одночасне вивчення і предмету, i мови. Цей метод зарекомендував себе надзвичайно ефективним способом навчання дорослої аудиторії у сфері бізнесу та менеджменту, пришвидшуючи когнітивні процеси опанування економічних категорій і понять, підвищуючи мотивацію до навчання і одночасно застосовуючи освоєні мовні навички в процесі набуття фахових знань.

\section{Результати та дискусії}

Когнітивний підхід, який отримав в англомовній лінгводидактиці назви Whole Language Content Approach, Cognitive Approach, Cognitive Academic Language Approach, спрямований на активізацію таких ментальних механізмів людини, як когніція (розуміння та усвідомлення), пам'ять, увага, мислення, інтелект. Поняття когніції одночасно позначають двома лат. словами: 
cognitio - «пізнання» та cognotatio - «мислення, міркування». Звідси це поняття включає в себе i процес пізнання, i психічні (ментальні) процеси сприйняття, категоризації та ін., які слугують для переробки інформації, усвідомлення й оцінки індивідом самого себе i довкілля. У процесі когніції сенсорно-перцептивні дані трансформуються в свідомості людини в ментальні репрезентації, які мають форму образу (гештальту/картинки, символу, уявлення, плану, схеми, фрейму, скрипту/сценарію), тобто «ментальні сутності, які кодують модально-специфічну інформацію про невербальний, перцептивний та сенсорно-моторний досвід», так звані імагени. Вербальну інформацію кодують «схожі на слова сутності, які містять візуальні й фонематичні ознаки й відзначаються амодальністю, тобто сприйняттям на рівні раціо» (Clark, 1987: 6). До них відносять поняття та пропозиції - так звані лологени. Подібні структури мозку дозволяють не тільки розпізнавати необхідну інформацію, відрізняти, диференціювати, класифікувати, категоризувати i концептуалізувати дані, а й допомагають утримувати їх в пам'яті.

Важко перебільшити значення роботи пам'яті в навчальному процесі, зокрема вивченні іноземної мови. Когнітивна психологія визначає пам'ять як «здатність живої системи фіксувати факт взаємодії 3 середовищем (зовнішнім або внутрішнім), зберігати результат цієї взаємодії у формі досвіду й використовувати його у поведінці» (Когнитивная, 2002: 79). Пам'ять щонайтісніше пов'язана 3 процесом переробки інформації в свідомості індивіда і має такі стадії, як: запам'ятовування (кодування), зберігання, пригадування (відтворення) та забування. Тривалість запам'ятовування й зберігання інформації пов'язують з короткочасною та довготривалою різновидами пам’яті; мету запам'ятовування - 3 умисною, довільною та мимовільною пам'яттю; канал надходження інформації - 3 візуальною, слуховою, образною, вербальною, моторною, емоційною видами пам’яті.

У навчальному процесі зазвичай задіяні два типи пам'яті короткочасна (оперативна/робоча) та довготривала. Етапи навчальної діяльності у формі завдань, настанов учителя утримуються в короткочасній пам'яті; лексичний багаж, правила оперування ним, знання мови в цілому отримуються 3 довготривалої пам'яті. Пам’ять і сприйняття дійсності працюють в тандемі. 
The Cognitive Approach to Teaching Students English Terminological...

У когнітивному підході до навчання іноземної мови особливої значущості набуває такий параметр, як «осмисленість матеріалу вивчення», який визначає результативність запам'ятовування. Зберігання інформації в свідомості визначають фактори тривалості та продуктивності. Останній співвідноситься 3 відчуттям мови й запам'ятовуванням іноземних слів, які мають фонематичну схожість зі словами рідної мови.

Відтворення, тж. упізнавання та пригадування - це ментальний процес, який відбувається між засвоєнням та відтворенням інформації в пам’яті людини і має безпосередню або відтерміновану форми. Йому також притаманний феномен ремінісиенції відтермінованого мимовільного пригадування. Важливу роль у відтворенні відіграє контекст: літера швидше сприймається у слові, значення слова легше виокремлюється в реченні, смисл речення однозначно розпізнається в тексті (Когнитивная, 2002: 150). Точність і швидкість упізнавання залежить від матеріалу (знайомий, осмислений): знайомий матеріал упізнається точніше, а осмислений - швидше. Помилки у відтворенні призводять до контамінації (плутанини) та конфабуляції (домислення).

Забування напряму пов'язане з запам'ятовуванням і корелює 3 таким поняттям, як «спонтанна динаміка сліду», тобто результатом роботи мнемічної системи мозку, яка працює асоціативним способом. На забування впливає модальність засвоєного матеріалу (образного, вербального тощо), його осмисленість і звичність. У навчальному процесі беруться до уваги ті фактори, що впливають на запам'ятовування і відповідно забування, а саме:

- число ментальних повторів, які залежать від того, наскільки довго інформація залишається в оперативній пам'яті;

- знаковість мовної одиниці, іiі схожість 3 опанованими поняттями (так зване знайоме відчуття);

- обсяг семантичної категорії (краще запам'ятовуються категорії 3 незначною кількістю елементів, напр., «types of companies», ніж категорії з великою їх кількістю, напр., «forms of business»);

- ступінь організації матеріалу та глибина його переробки відповідно до поточних і стратегічних завдань;

- інтенція на запам'ятовування і володіння його стратегіями (довільне - мимовільне). 
Когнітивний підхід у навчанні студентів англійської термінолексики...

Згідно з експериментальними даними, матеріал, пов’язаний 3 метою, запам'ятовується краще у порівнянні 3 матеріалом, пов'язаним з умовами досягнення цієї мети (Зинченко, 2002).

Пізнавальна діяльність людини багато в чому залежить від такої властивості свідомості, як увага. Людина не може одночасно охопити увесь навколишній світ і саму себе. Щось завжди виступає на перший план, щось залишається в тіні, щось взагалі відсутнє в свідомості. В. Вундт визначає увагу як чіткий стан свідомості, у якому відбувається найбільш виразне сприйняття дійсності (Вундт, 1992). Увага - це ще й стан зосередженості (концентрації) на одному предметі. Звідси основними функціями уваги $є$ селективність та регуляція діяльності. Як справедливо зауважує О.Р. Лурія, увага відображає спрямування усієї діяльності людини, і саме в ній знаходить вираження відношення суб'єкта до об'єкта (Лурия, 1973). Зосередження уваги, на думку вчених, має велике значення для переробки лексичної інформації. Виокремлюють сім чинників, які впливають на концентрацію уваги під час навчання: частотність, вибірковість, сприйняття, інструкція, індивідуальна здатність, готовність до мовленнєвої діяльності та вимоги до завдання (Мельник, 2014: 127). Не менш вагомими для навчання іншомовної лексики є також презентація матеріалу, особистість студента та його обізнаність з предметом.

Мислення - це інтегральна властивість свідомості, у якій беруть участь усі інші психічні процеси: когніція, пам'ять, увага та ін.; діяльність мозку, у якому реалізується інтелект. С.Л. Рубінштейн у 1946 р. визначав мислення як опосередковане й узагальнене пізнання об'єктивної реальності (Рубинштейн, 1946). Філософський енцииклопедичний словник за редакцією В.І. Шинкарука надає розширене тлумачення мислення як інформаційної діяльності, що набула ознак опосередкованого, узагальненого пізнання об'єктивної реальності, яке за допомогою абстрагування, міркувань (зіставлення пізнавальних образів та логічного виведення думок) і типізації даних про світ явищ розкриває їхні зв'язки, закономірності, тенденції розвитку (ФЕС, 2002: 378). Мислення $є$ опосередкованим у тому сенсі, що воно виходить за межі безпосереднього споглядання дійсності, й узагальненим, тому що на базі сприйняття конкретного образу створює узагальнений (абстрактний) образ існуючих об'єктів (наочно даних чи уявних, ідеалізованих). 
The Cognitive Approach to Teaching Students English Terminological...

Процес мислення безпосередньо пов'язаний 3 поняттям «інтелект» (від лат. intellectus - «відчуття, сприйняття, розуміння»). Інтелект - це інформаційний потенціал знань людини, отриманий в результаті діяльності свідомості та мислення; сукупність розумових здібностей і рівень розумового розвитку (Інтелект/Вікіпедія). За походженням інтелект $\epsilon$ сконцентрованим досвідом вирішення проблем, надбаним впродовж життя й частково успадкованим від предків. Психологія тлумачить інтелект як відносно стійку структуру розумових здібностей людини, який включає в себе досвід, набуті знання і здатність швидко й доцільно використовувати ïх у нових ситуаціях та у процесі розв'язання складних завдань (Інтелект/Основи). Льюїс Терстоун відносить до структури інтелекту наступне:

- здатність оперувати числами та виконувати арифметичні дії;

- вербальні навички й уміння;

- просторову орієнтацію і просторову уяву;

- пам'ять;

- здатність до міркування;

- здатність швидко визначати спільні й відмінні ознаки предметів та їхніх зображень (Thurstone, 1999).

3 розвитком кібернетики намітилася тенденція до розуміння інтелекту як пізнавальної діяльності будь-яких систем, здатних до навчання, цілеспрямованої переробки інформації та саморегулювання (Інтелект/Загальна). Результати досліджень свідчать про високий рівень генетичної обумовленості інтелекту. Найвищий рівень спадковості простежується у вербальному інтелекті, дещо нижчий - у невербальному. Індивідуальний рівень розвитку інтелекту визначається багатьма чинниками, зокрема «інтелектуальним кліматом» оточення, середовищем спілкування i навчання. Інтелект відіграє провідну роль у вирішенні академічних i практичних завдань, плануванні діяльності, здатності робити висновки, передбачати наслідки, вносити корективи, набувати практичний досвід.

Процес мислення, у якому не останню роль відіграє інтелект, визначається низкою логічних операцій: порівняння, ототожнення, поділу/диз'юнкції, об'єднання/кон'юнкції, аналізу і синтезу, абстрагування, узагальнення, класифікації, типологізації, 
Когнітивний підхід у навчанні студентів англійської термінолексики...

категоризації, концептуалізації, формулювання понять і суджень, умовиводу тощо.

Для свідомого вивчення фахової лексики рекомендуємо когнітивно орієнтовані вправи, які корелюють 3 логічними операціями мислення: вибір (multiple choice), пошук зайвого слова (odd word), вирішення пазлів і кросвордів, гра в доміно/бінго, складання половинок речень, віднаходження термінів у таблиці 3 літер. Доречним є також навчання студентів здогадці значення слова 3 контексту, складання асоціативних ментальних карт і вирішення проблемних ситуацій.

Навчальні програми 3 вивчення фахової термінолексики, зокрема економічної, традиційно укладають за тематичним принципом, що загалом узгоджується 3 когнітивним підходом, який передбачає процес категоризації i тематизації понять, що сприяє кращому розумінню й засвоєнню лексичної інформації. У цьому контексті когнітивно орієнтовані вправи мають органічно вписуватися у вивчення конкретної навчальної теми. Напр., опанування теми «marketing» за навчальним посібником з англійської ділової мови Business English Course (Naumenko, 2014) пропонуємо доповнити низкою когнітивних вправ. До них належать: вправи на вибір потрібної лексичної інформації, групування, здогадку 3 контексту, логічне мислення, мовну гру, асоціативне мислення, вирішення проблемної ситуації. Приклади когнітивно орієнтованих вправ наводимо нижче.

I. Exercises on making choice.

1. Choose the key word in each aphorism:

1.1 A new product creates a new market (Alfred Sloan)

1.2 The purpose of business is to create a customer (Peter Drucker)

1.3 The customer is king (Alfred Sloan) (Prompt: product, market, customer)

2. State the odd word in the lines of synonyms.

2.1 product, goods, bonus, merchandise.

2.2 market, premises, bazaar, mart.

2.3 customer, client, consumer, distributer.

3. Multiple choice: Choose the right definition from three possible (They may be more than one). 
The Cognitive Approach to Teaching Students English Terminological...

\section{marketing concept}

a) not to sell what is made but to make what is bought;

b) to find wants and to fill them;

c) to create and anticipate the consumer needs. «white elephant»

portfolio theory

a) product which is very big;

b) product which has little demand;

c) product which has no demand. a) position and duties of the minister of state;

b) securities owned by a person or a bank;

c) an offer of several products to several markets.

4. Name the stages of the product life cycle. (Refer to the Product Life Cycle scheme if necessary (Naumenko, 2014: 115)).

At this stage sales are slow as both consumers and distributers are becoming aware of the product and adopting to it. in sales.

At this stage there is rapid acceptance of the product and increase

At this stage sales and profits are still high but there is considerable investment in product changes, promotional activity and price-cutting.

At this stage the product is re-launched, usually with new features, different packaging, and even a new image.

This stage is marked by falling off in sales.

II. Exercises on grouping.

5. Match each word in column A with one or more words in column B.

\begin{tabular}{|c|c|}
\hline column A & column B \\
\hline \multicolumn{2}{|c|}{ Model N $+N$} \\
\hline market & awareness \\
\hline marketing & decline \\
\hline consumer & $\operatorname{mix}$ \\
\hline product & share \\
\hline portfolio & concept \\
\hline sales & segment \\
\hline trademark & demand \\
\hline \multicolumn{2}{|c|}{ Model V + N } \\
\hline to enter & sales \\
\hline to launch & awareness \\
\hline to bring down & risk \\
\hline to increase & the market \\
\hline to research & prices \\
\hline to segment & overheads \\
\hline to reduce & a product \\
\hline \multicolumn{2}{|c|}{ Model A + N } \\
\hline profitable & $\operatorname{cost}$ \\
\hline generic & customer \\
\hline
\end{tabular}




\begin{tabular}{ll} 
existing & stage \\
limited & goods \\
mature & needs \\
total & type \\
potential & resources \\
\hline
\end{tabular}

\section{Exercises on guesswork.}

6. Vocabulary in context. Guess from the context what segment of buyers the four stages of family life cycle refer to. (You may use the prompt below).

Such products as cars, food, household items are often segmented by the stage of family life cycle that identifies potential consumers by age, marital status, number and age of children. The four main stages of the family life cycle are:

1) bachelor stage

2) full nest

3) empty nest

4) solitary survivors

(The prompt: older married couples with no children; young single individuals; older single or widowed people; young married couples with children)

\section{Exercises on logical thinking.}

7. Dictionary definition. Consider the three possible definitions of the notion «marketing» in small groups, compose your own one on the basis of them.

(1) «sales, distribution, advertising and promotion, product planning and market research»;

(2) «assessment of consumer needs and making them consistent with the company objectives»;

(3) «the process of identification, anticipation and supplying the customer needs efficiently and profitably».

Важливим елементом цього типу вправ є обговорення варіантів дефініцій, виявлення в них обов'язкових i другорядних ознак поняття, аналіз помилок, пов'язаних із недостатнім розумінням номінативних значень слів та фахових понять, які вони позначають.

\section{Language games.}

8. Complete the crossword. Refer for the prompt to the text if necessary. 
The Cognitive Approach to Teaching Students English Terminological...

\section{Across}

1. Stimulation of the product demand.

2. Consumer goods which are bought infrequently and last long.

3. The simplest pricing model is cost

4. The highest quality product.

5. A member of a marketing team.

\section{Down}

6. Companies analyse their offerings according to the theory.

7. The percentage of total sales of one product or trademark in the market.

8. The highest point of product sales is called the stage.

9. The 4 components of marketing are also called the marketing

10. The total market with a certain type of customer.

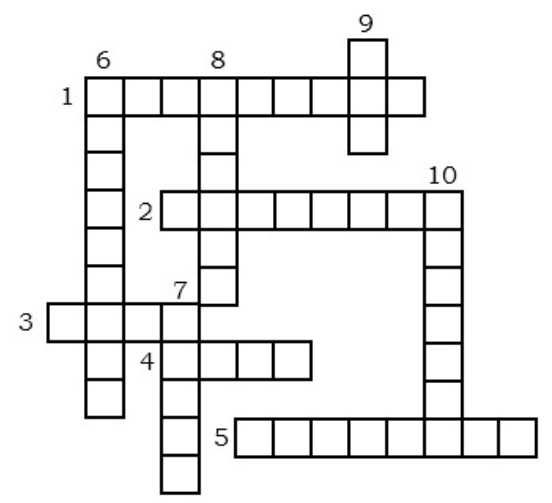

\section{Exercises on associative thinking.}

9. Mental maps. Complete the radial diagram with language associations referring to the notion «marketing».

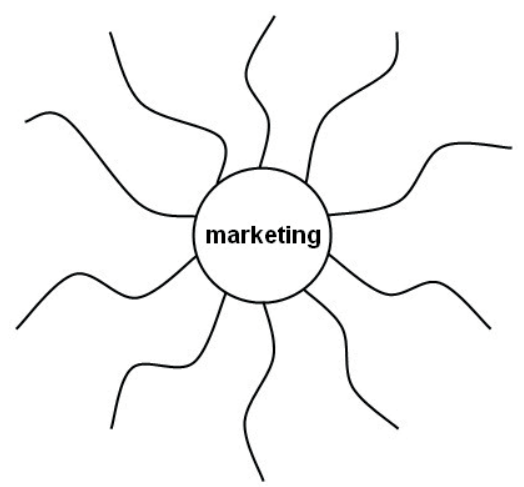


Когнітивний підхід у навчанні студентів англійської термінолексики...

(The prompt: possible associations: market, product, segment, demand, promotion, sales, trademark, market share, PLC, 4 P's I marketing mix).

Різновид вправ «ментальна карта», що грунтується на принципі «радіального мислення», дозволяє розблокувати творчу уяву учнів, полегшити запам'ятовування, активізувати увагу та словниковий запас, структурувати інформацію у візуальній формі.

\section{Problem-solving exercises.}

10. Consider the following real-to-life situations corresponding to the problems of product selling and market segmentation of «The English Language Centre» in small groups. Suggest a possible collective solution. strategies:

1. Growing sales: How to grow sales of a brand. Possible

a) diversification of a product (new products, new markets);

b) product development (new features to the current product);

c) better service;

d) pricing (lowering prices, benefits, sales promotion, cutting costs).

2. Market segmentation. Segmentation circle: choosing a market coverage strategy.

a) demographics: age, gender, family life cycle;

b) psychographics: self concept, lifestyle;

c) usage rate (heavy users, light users);

d) benefits sought (those looking for additional benefits).

Вправи на вирішення проблемної ситуації розвивають евристичні здібності, аналітичні вміння, логіку мислення та творчу активність учнів, стимулюють дослідницьку діяльність, активізують предметні знання та знання іноземної мови, сприяють засвоєнню нових знань.

\section{Висновки}

Проведений аналіз дозволяє зробити такі висновки. Когнітивний підхід, що застосовується до вивчення іншомовної лексики i як такий, що активно розвивається в сучасній лінгводидактиці, $є$ безумовно одним із перспективних напрямів свідомого навчання студентів вишів. Ефективність когнітивного підходу полягає в раціональній методичній роботі 3 лексичним матеріалом під час навчального процесу з опорою на такі складові 
The Cognitive Approach to Teaching Students English Terminological...

суб'єкта навчання, як когніція, пам'ять, увага, мислення, інтелект, індивідуальність учня. Враховуючи об'єктивні труднощі, пов'язані 3 вивченням економічної термінолексики студентами нефахових спеціальностей (наприклад, необізнаність 3 предметною галуззю), когнітивно спрямовані вправи вважаємо ефективними, особливо у поєднанні 3 такими інтерактивними практиками, як ігрове та проблемне навчання.

У подальшому плануємо вивчення теоретичних підходів до розроблення когнітивних вправ типу «mental map» (ментальна карта) та «рroblem-solving» (вирішення проблеми), орієнтованих на навчання студентів англійської бізнес-лексики у нефахових вишах.

\section{Література}

Боднар С.В. Когнітивний підхід до формування лексичної компетентності студентів економічних спеціальностей. Наука і освіта. 2014. № 10. С. 34-38.

Борщовецька В.Д. Навчання студентів-економістів англійської фахової лексики: дис. ... канд. пед. наук: 13.00.02. Київ: КДЛУ, 2004. 283 с.

Вундт В. Введение в психологию. Москва: КомКнига, 1992. 168 с.

Зинченко П.И. Непроизвольное запоминание. Москва: Директмедиа Паблишинг, 2002. 717 с.

Інтелект. Вікіпедія. URL: https://uk.wikipedia.org (дата звернення: 19.01.2018).

Когнитивная психология / под ред. В.Н. Дружинина, Д.В. Ушакова. Москва: ПЕР СЭ, 2002. $480 \mathrm{c}$.

Крупченко А.К., Кузнецов А.Н. Основы профессиональной лингводидактики: монография. Москва: АПКиППРО, 2015. 232 с.

Лурия А.Р. Основы нейропсихологии. Москва: Академия, 2003. 384 с.

Мельник Р.А. Когнітивний підхід до навчання спеціальної лексики студентівекономістів. Науковий часопис НПУ імені М.П. Драгоманова. Серія 5 Педагогічні науки: реалії та перспективи. 2014. Вип. 49. С. 124-129.

Рубинштейн С.Л. Основы общей психологи. СПб.: Питер, 2002. 720 с.

Філософський енциклопедичний словник / за. ред. В.І. Шинкарук. Київ: Абрис, 2002. $740 \mathrm{c}$.

Akin, L. (2017). A Study of the Effects of Thinking Maps ${ }^{\circledR}$ on the Achievement of Students in Middle Class Science: Doctor's thesis. Columbus State University.

Alloway, T.P., Bibile, V., \& Lau, G. (2013). Computerized Working Memory Training: Can it lead to gains in cognitive skills in students? Computers in Human Behavior, 29, 632-638. doi: 10.1016/j.chb.2012.10.023

Astor, I. (2008). The Effectiveness of Thinking Maps in Improving the Achievement and Skills beyond the Knowledge among First-Grade Secondary Students in Logic Course. Studies in Curriculums and Teaching Methods, 132, 21-81.

Channel, J., Carter, R., \& McCarthy, M. (1996). Psychological Considerations in the Study of L2 Vocabulary Acquisition. Vocabulary and Language Teaching, (pp. 83-95). London, New York: Longman.

Chien, J.M., \& Morrison, A.B. (2010). Expanding in Mind's Workspace: Training and transfer effects with a complex working memory span task. Psychonomic Bulletin and Review, 17(2), 193-199. doi: 10.3758/PBR.17.2.193 
Когнітивний підхід у навчанні студентів англійської термінолексики...

Clark, J.M., \& Paivio, A.A. (1987). Dual Coding Perspective on Encoding Processes. Imagery and Related Mnemonic Process. Theories, Individual Differences, and Applications. M. McDaniel, M. Pressley (Eds.). Retrieved from https://www. springer.com

Conway, A.R.A., Kane, M.J., \& Engle, R.W. (2003). Working Memory Capacity and its Relation to General Intelligence. Trends in Cognitive Sciences, 7(12), 547552. doi: $10.1016 /$ j.tics.2003.10.005

Hassan, S.R., Rosli R., \& Zakaria, E. (2016). The Use of i-think Map and Questioning to Promote Higher-Order Thinking Skills in Mathematics. Creative Education, 7(7), 1069-1078. doi: 10.4236/ce.2016.77111

Huang, L. (2015). Grouping by Similarity is Mediated by Feature Selection: Evidence from the Failure of Cue Combination. Psychonomic Bulletin and Review, 22(5), 1364-1369. doi: 10.3758/513423-015-0801-z

Jaeggi, S.M., Buschkuehi, M., Jonides, J., \& Shah, P. (2011). Short- and Longterm Benefits of Cognitive Training. Proceedings of the National Academy of Sciences of the United States of America, 108(25), 10081-10086. doi: 10.1073/ pnas. 1103228108

Naumenko, L. (2014). Business English Course. Kyiv: Logos [in English].

Rosch, E. (1983). Prototype Classification and Logical Classification. The Two Systems. New Trends in Conceptual Representation Challenges to Piaget's Theory? (pp. 73-86), Hillsdale: Lawrence Enbaum Publ.

Shipstead, Z., Redick, T.S., \& Engle, R.W. (2012). Is Working Memory Training Effective? Psychological Bulletin, 138(4), 628-654. doi: 10.1037/a0027473

Snider, J.G. \& Osgood, C.E. (Eds.) (1969). Semantic Differential Technique. Chicago: Aldine Publ.

Solso, R. (2001). Cognitive Psychology. Boston: Allyn \& Bacon.

Thurstone, L. (1999). The Nature of Intelligence. Abingdon-on-Thames: Routledge.

Vovk, Y.I. (2012). Cognitive Approach to Language Teaching. European Researcher, 35(11-3), 2056-2059.

Wierzbizka, A. (1972). Semantic Primitives. Frankfurt/M.: Athenaum-Verl.

\section{References}

Bodnar, S.V. (2014). Kognityvny pidhid do formuvannia leksychnoyi kompetentnosti studentiv ekonomichnykh spetsialnostey [Cognitive approach to forming lexical competence of students of economic specialties]. Nauka i osvita - Science and Education, 10, 34-38 [in Ukrainian].

Borshchovetska, V.D. (2004). Navchannia studentiv-economistiv angliyskoyi fakhovoyi leksyky [Teaching Students-Economists English Special Lexis]. Candidate's thesis. Kyiv: KeivSLU [in Ukrainian].

Vundt, V. (1992). Vvedeniye v psikhologiyu [Introduction to Psychology]. Moscow: KomKniga [in Russian].

Zinchenko, P.I. (2002). Neproizvolnoye zapominaniye [Involuntary Memorizing]. Moscow: Direktmedia Publishing [in Russian].

Intelekt [Intelligence]. Vikipediya [Wikipedia]. Retrieved from https://uk.wikipedia.org [in Ukrainian].

Druzhinin, V.N., \& Ushakov, D.V. (Eds.) (2002). Kognityvnaya psyhologiya [Cognitive Psychology]. Moscow: PER SE [in Russian]. 
The Cognitive Approach to Teaching Students English Terminological...

Krupchenko, A.K., \& Kuznetsov, A.N. (2015). Osnovy professionalnoi lingvadidaktiki [The Fundamentals of Professional Lingual Didactics]. Moscow: APKiPPRO [in Russian].

Luriya, A.R. (2003). Osnovy neiropsikhologii [The Fundamentals of Neuropsychology]. Moscow: Akademiya [in Russian].

Melnyk, R.A. (2014). Kognityvny pidhid do navchannia spetsialnoyi leksyky studentiv-ekonomistiv [Cognitive Approach to Teaching Special Lexis StudentsEconomists]. Naukovyi chasopys NPU imeni M.P. Dragomanova - Scientific Journal of NPU named after M.P. Dragomanov, 49, 124-129 [in Ukrainian].

Rubinshtein, S.L. (2002). Osnovy obshchei psikhologii [The Fundamentals of General Psychology]. St.Petersburg: Piter [in Russian].

Shynkaruk, V.I. (Ed.) (2002). Filosofskyi entsyklopedychnyi slovnyk [Philosophical Encyclopedic Dictionary]. Kyiv: Abrys [in Ukrainian].

Akin, L. (2017). A Study of the Effects of Thinking Maps ${ }^{\circledR}$ on the Achievement of Students in Middle Class Science: Doctor's thesis. Columbus State University.

Alloway, T.P., Bibile, V., \& Lau, G. (2013). Computerized Working Memory Training: Can it lead to gains in cognitive skills in students? Computers in Human Behavior, 29, 632-638. doi: 10.1016/j.chb.2012.10.023

Astor, I. (2008). The Effectiveness of Thinking Maps in Improving the Achievement and Skills beyond the Knowledge among First-Grade Secondary Students in Logic Course. Studies in Curriculums and Teaching Methods, 132, 21-81.

Channel, J., Carter, R., \& McCarthy, M. (1996). Psychological Considerations in the Study of L2 Vocabulary Acquisition. Vocabulary and Language Teaching, (pp. 83-95). London, New York: Longman.

Chien, J.M., \& Morrison, A.B. (2010). Expanding in Mind's Workspace: Training and transfer effects with a complex working memory span task. Psychonomic Bulletin and Review, 17(2), 193-199. doi: 10.3758/PBR.17.2.193

Clark, J.M., \& Paivio, A.A. (1987). Dual Coding Perspective on Encoding Processes. Imagery and Related Mnemonic Process. Theories, Individual Differences, and Applications. M. McDaniel, M. Pressley (Eds.). Retrieved from https://www. springer.com

Conway, A.R.A., Kane, M.J., \& Engle, R.W. (2003). Working Memory Capacity and its Relation to General Intelligence. Trends in Cognitive Sciences, 7(12), 547552. doi: 10.1016/j.tics.2003.10.005

Hassan, S.R., Rosli R., \& Zakaria, E. (2016). The Use of i-think Map and Questioning to Promote Higher-Order Thinking Skills in Mathematics. Creative Education, 7(7), 1069-1078. doi: 10.4236/ce.2016.77111

Huang, L. (2015). Grouping by Similarity is Mediated by Feature Selection: Evidence from the Failure of Cue Combination. Psychonomic Bulletin and Review, 22(5), 1364-1369. doi: 10.3758/513423-015-0801-z

Jaeggi, S.M., Buschkuehi, M., Jonides, J., \& Shah, P. (2011). Short- and Longterm Benefits of Cognitive Training. Proceedings of the National Academy of Sciences of the United States of America, 108(25), 10081-10086. doi: 10.1073/ pnas. 1103228108

Naumenko, L. (2014). Business English Course. Kyiv: Logos [in English].

Rosch, E. (1983). Prototype Classification and Logical Classification. The Two Systems. New Trends in Conceptual Representation Challenges to Piaget's Theory? (pp. 73-86), Hillsdale: Lawrence Enbaum Publ. 
Когнітивний підхід у навчанні студентів англійської термінолексики...

Shipstead, Z., Redick, T.S., \& Engle, R.W. (2012). Is Working Memory Training Effective? Psychological Bulletin, 138(4), 628-654. doi: 10.1037/a0027473

Snider, J.G. \& Osgood, C.E. (Eds.) (1969). Semantic Differential Technique. Chicago: Aldine Publ.

Solso, R. (2001). Cognitive Psychology. Boston: Allyn \& Bacon.

Thurstone, L. (1999). The Nature of Intelligence. Abingdon-on-Thames: Routledge.

Vovk, Y.I. (2012). Cognitive Approach to Language Teaching. European Researcher, 35(11-3), 2056-2059.

Wierzbicka, A. (1972). Semantic Primitives. Frankfurt/M.: Athenaum-Verl.

\section{АНОТАЦІЯ}

Стаття присвячена вивченню передумов застосування когнітивного підходу у навчанні англійської термінолексики предметної галузі "мікроекономіка" студентів нефахових вишів. Розглянуті такі поняття, як «когніція», "пам'ять», "увага», «мислення», «інтелект», які забезпечують розумову діяльність студента в процесі навчання. Напрацьована система когнітивно орієнтованих вправ з вивчення англійської економічної термінолексики, яка містить сім типів: вправи на вибір потрібної лексичної інформації, групування, здогадку з контексту, логічне мислення, мовну гру, фрормулювання наукових дефініцій, асоціативне мислення, вирішення проблемної ситуації, і ґрунтується на логічних операціях порівняння, ототожнення, поділу / диз'юнкції, об'єднання / кон'юнкції, аналізу і синтезу, абстрагування, узагальнення, класифікації, типологізації, категоризації, концептуалізації, умовиводу, формулювання понять і суджень. Вправи відібрані за тематичним принципом (за темою "Marketing» з авторського посібника "Business English Course») і складають такі різновиди: визначення ключового слова, визначення зайвого слова, множинний вибір, віднаходження потрібної назви, групування слів за семантичною узгодженістю, здогадка з контексту, фрормулювання дефініцій, розгадування кросворду, заповнення радіальної діаграми ментальної карти мовними реакціямиасоціаціями на слово marketing, вирішення наближеної до реальної проблемної ситуації, пов'язаної з маркетинговою діяльністю, в малій групі і формулювання ділової пропозиції. Відібрані вправи розвивають евристичні здібності, аналітичні вміння, логіку мислення та творчу уяву учнів, полегшують запам'ятовування, посилюють увагу, активізують предметні знання та знання іноземної мови, сприяють засвоєнню нових знань, структурують інформацію у мовній та візуальній формах, стимулюють дослідницьку діяльність.

Ключові слова: когнітивний підхід, термінолексика, предметна галузь "мікроекономіка», логічні операції мислення, когнітивна методика. 
The Cognitive Approach to Teaching Students English Terminological...

Науменко Людмила, Олийнык Оксана. Когнитивный подход в обучении студентов английской терминолексике предметной сферы «микроэкономика»

\section{АННОТАЦИЯ}

Статья посвящена изучению предпосылок применения когнитивного подхода в обучении английской терминолексике предметной сферы «микроэкономика» студентов неспециальных вузов. Рассмотрены такие понятия, как «когниция», "память», "внимание», "мышление», "интеллект», которые обеспечивают умственную деятельность студента в процессе обучения. Наработана система когнитивно ориентированных упражнений для изучения английской экономической терминолексики, которая включает семь типов: упражнения на выбор нужной лексической информации, группирование, догадку из контекста, логическое мышление, формулирование научных дефиниций, решение проблемной ситуации, и базируется на логических операциях сравнения, отождествления, разделения / дизъюнкции, объединения / конъюнкции, анализа и синтеза, абстрагирования, обобщения, классификации, типологизации, категоризации, концептуализации, умозаключения, формулирования понятий и суджений. Упражнения отобраны за тематическим принципом (за темой "Marketing» из авторского пособия "Business English Course») i состоят из таких видов: определение ключового слова, определение лишнего слова, множественный выбор, поиск нужного названия, группирование слов за семантической согласованностью, догадка из контекста, формулирование дефиниций, разгадывание кросворда, заполнение радиальной диаграммы ментальной карты языковыми реакциямиассоциациями на слово marketing, решение приближенной к реальной проблемной ситуации, связанной с маркетинговой деятельностью, в малой группе и формулирование делового предложения. Отобраные упражнения розвивают эвристические способности, аналитические умения, логику мышления и творческое воображение учеников, облегчают запоминание, усиливают внимание, активизируют предметные знания и знания иностранных языков, способствуют усвоению новых знаний, структурируют информацию в языковой и визуальной формах, стимулируют исследовательскую деятельность.

Ключевые слова: когнитивный подход, терминолексика, предметная сфера "микроэкономика», логические операции мышления, когнитивная методика. 